\title{
ANALISIS KESALAHAN KONSEP DAN STRUKTUR PENGETAHUAN MAHASISWA SERTA PERBAIKANNYA MENGGUNAKAN WAWANCARA BERBASIS KONFLIK KOGNITIF PADA TOPIK IKATAN KIMIA
}

\author{
Yuski Sudana, Subandi, \& Aman Santoso \\ Universitas Negeri Malang, Jl. Semarang 5 Malang \\ e-mail: sudanayuski@gmail.com atau subandi.fmipa@um.ac.id
}

\begin{abstract}
Analysis of Students' Misconceptions and Knowledge Structure and Their Improvements Using Cognitive Conflict-Based Interview on Chemical Bond Topic. The aims of this mixedmethod study are to investigate (1) the types of students' misconceptions in chemical bonding topics, measured using a two-tier diagnostic test as well as a concept-map test, (2) the students' knowledge structures, and (3) the effectiveness of cognitive-conflict based interviews to remedy students' misconceptions and to improve the level of students' knowledge structures. This study involved the firstsemester students majoring in chemistry. The results show that (1) there are 10 types of students' misconceptions in chemical bonding topics, with the conformity level of misconception identification of $50.94 \%$ (moderate) between the concept-map test and the two-tier diagnostic test is (2) most of the students $(66.67 \%)$ have a low level of knowledge structures, and (3) cognitive-conflict based interviews are found to be effective in dealing with students' misconceptions and in improving their knowledge structures.
\end{abstract}

Keywords: misconceptions; knowledge structure; cognitive-conflict based interviews; chemical bonding

\begin{abstract}
Abstrak: Analisis Kesalahan Konsep dan Struktur Pengetahuan Mahasiswa Serta Perbaikannya Menggunakan Wawancara Berbasis Konflik Kognitif pada Topik Ikatan Kimia. Tujuan penelitian ini adalah untuk mengetahui 1) jenis-jenis kesalahan konsep mahasiswa pada topik ikatan kimia, baik yang diidentifikasi menggunakan tes two tier, maupun yang menggunakan tes peta konsep (2) struktur pengetahuan mahasiswa, dan (3) keefektifan wawancara berbasis konflik kognitif dalam memperbaiki kesalahan konsep dan struktur pengetahuan mahasiswa. Penelitian ini merupakan penelitian campuran (mixed-methods) dengan subject penelitian adalah mahasiswa semester 1 jurusan kimia yang telah memperoleh materi ikatan kimia. Hasil penelitian menunjukkan bahwa (1) terdapat 10 jenis kesalahan konsep mahasiswa pada topik ikatan kimia, tingkat kesesuaian identifikasi kesalahan konsep menggunakan tes peta konsep dengan tes diagnostik two-tier rata-rata sebesar 50,94\% (sedang), (2) sebagian besar mahasiswa $(66,67 \%)$ memiliki struktur pengetahuan yang rendah dan dan (3) wawancara berbasis konflik kognitif efektif dalam memperbaiki kesalahan konsep dan struktur pengetahuan mahasiswa.
\end{abstract}

Kata kunci: kesalahan konsep; struktur pengetahuan; wawancara berbasis konflik kognitif; ikatan kimia

Ikatan kimia merupakan salah satu topik paling fundamental dalam mempelajari ilmu kimia baik di SMA maupun di perguruan tinggi (Taber \& Coll, 2003 ; Vrabec \& Proksa, 2016 ). Namun beberapa penelitian telah menunjukan bahwa masih banyak siswa yang mengalami kesalahan konsep pada topik ini. Kesalahan konsep terjadi ketika pema- haman siswa tentang suatu konsep tertentu berbeda dengan penjelasan ilmiah secara umum, Sebagai contoh kesalahan konsep ditemukan adalah bahwa siswa menganggap (1) ikatan ionik hanya terjadi antara atom logam dengan atom non logam (Luxford \& Bretz, 2013), (2) atom-atom yang berikatan kovalen memiliki perbedaan keelektronegatifan 
yang sangat besar (Luxford \& Bretz, 2014) dan (3) pada pembentukan ikatan kovalen terjadi transfer elektron (Vrabec \& Proksa, 2016).

Salah satu penyebab terjadinya kesalahan konsep adalah karakteristik konsep-konsep dalam topik ikatan kimia yang bersifat berjenjang yang artinya untuk memahami konsep yang tingkatannya lebih tinggi diperlukan pemahaman yang benar terhadap konsep yang lebih dasar (Effendy, 2002). Jika satu konsep dasar tidak dapat dipahami dengan baik dan benar, maka akan berakibat timbulnya kesalahan konsep dikarenakan pebelajar kesulitan atau tidak dapat membuat hubungan yang koheren antara satu konsep dengan konsep yang lain dalam struktur pengetahuannya (Novak, 2010).

Struktur pengetahuan adalah suatu skema yang dibuat oleh pebelajar dalam mengatur dan menghubungkan berbagai konsep untuk memahami topik pembelajaran tertentu (Novak \& Canas, 2006; Novak, 2010). Struktur pengetahuan mahasiswa merupakan indikator keberhasilan dalam pembelajaran kimia (Lopez, dkk., 2014). Struktur pengetahuan mahasiswa dapat diidentifikasi dan dianalisis melalui gambaran peta konsep mahasiswa, khususnya melalui frasa penghubung antar konsep yang kemudian dikonfirmasi melalui wawancara (Burrows \& Mooring, 2014). Oleh sebab itu, teknik peta konsep diduga dapat digunakan untuk mengetahui struktur pengetahuan dan kesalahan konsep, karena melalui peta konsep memungkinkan peneliti untuk memvisualisasikan kemampuan siswa dalam menghubungkan satu konsep dengan konsep yang lain (Wheeldon \& Faubert, 2009). Analisis struktur pengetahuan perlu dilakukan untuk mengungkap kesalahan konsep mahasiswa secara menyeluruh. Struktur ini akan berubah jika telah terjadi perbaikan dari kesalahan konsep itu. dan melihat perbedaan struktur pengetahuan mahasiswa pasca perbaikan kesalahan konsep, sehingga diperlukan suatu strategi pembelajaran yang sesuai untuk memperbaiki kesalahan konsep mahasiswa.

Salah satu strategi pembelajaran yang mampu memperbaiki kesalahan konsep adalah strategi konflik kognitif. Khodaryah (2010) telah melaporkan bahwa pembelajaran dengan strategi konflik kognitif secara signifikan efektif untuk mengurangi kesalahan konsep siswa pada topik larutan penyangga dengan persistensi kesalahan konsep sebesar 14,6\% setelah tiga minggu perlakuan. Di samping dilaksanakan selama pembelajaran yang umum, strategi konflik kognitif juga dapat diterapkan dengan wawancara semiterstruktur. Menurut Bretz (2007), wawancara semi terstruktur memberi peluang siswa untuk menjawab pertanyaan pewawancara dengan bebas sesuai dengan pemahaman konsepnya. Hal ini akan membantu pewawancara untuk menggali lebih dalam tentang konstruksi kognitif siswa dalam memahami suatu konsep (Schonborn, dkk., 2007). Hasil penelitian Linerberger \& Bretz (2012) menunjukkan bahwa wawancara berbasis konflik kognitif mampu mengungkap kesalahan konsep mahasiswa sekaligus meningkatkan kemampuan mahasiswa dalam membuat hubungan yang koheren antar konsep dalam struktur pengetahuannya. Berdasarkan paparan tersebut, maka penelitian ini bertujuan untuk mengetahui (1) jenisjenis kesalahan konsep mahasiswa pada topik ikatan kimia, baik yang diidentifikasi menggunakan tes two tier, maupun yang menggunakan tes peta konsep, (2) struktur pengetahuan mahasiswa, dan (3) keefektifan wawancara berbasis konflik kognitif dalam memperbaiki kesalahan konsep dan struktur pengetahuan mahasiswa.

\section{METODE}

Penelitian ini merupakan penelitian campuran (mixed-methods) dimana proses pengumpulan data kuantitatif dan kualitatif dilakukan secara bersamasama/simultan (Cresswell, 2016). Metode penelitian kualitatif ditujukan untuk mendeskripsikan kesalahan konsep dan struktur pengetahuan mahasiswa yang masing-masing dianalisis berdasarkan hasil tes diagnostik two-tier dan peta konsep yang selanjutnya dikonfirmasi menggunakan wawancara. Metode penelitian kuantitatif ditujukan untuk mengetahui keefektifan wawancara berbasis konflik kognitif dalam memperbaiki kesalahan konsep dan struktur pengetahuan mahasiswa. Rancangan penelitian kuantitatif yang digunakan adalah pra eksperimental dengan desain One Group Design Pre-test Post-test. Subyek dalam penelitian ini adalah 24 orang mahasiswa semester 1 jurusan kimia salah satu Universitas di Malang, angkatan 2017 yang sebelumnya telah mendapatkan materi ikatan kimia.

Ada dua jenis instrumen yang digunakan dalam penelitian ini yaitu instrumen pengukuran dan instrumen perlakuan. Instrumen pengukuran merupakan instrumen yang digunakan untuk mengidentifikasi kesalahan konsep dan struktur pengetahuan mahasiswa, yaitu berupa 18 butir soal diagnostik two-tier yang dikembangkan oleh Fajar (2014) dengan nilai reliabilitas sebesar 0,863 dan instrumen test peta konsep yang diadopsi Burrows \& Morning (2014). Instrumen perlakuan yang digunakan dalam penelitian ini berupa pedoman/protokol wawancara berbasis konflik kognitif yang telah divalidasi. 


\section{HASIL DAN PEMBAHASAN}

Ada tiga hasil penelitian yang diperoleh, yaitu (1) jenis-jenis kesalahan konsep yang dialami mahasiswa, yang menggunakan tes diagnostik two-tier dan maupun yang menggunakan tes peta konsep (2) struktur pengetahuan mahasiswa dalam topik ikatan kimia, dan (3) keefektifan wawancara berbasis konflik kognitif dalam memperbaiki kesalahan konsep dan struyktur pengetahuan mahasiswa.

\section{Jenis-Jenis Kesalahan Konsep Mahasiswa}

Berdasarkan hasil tes diagnostik two-tier ditemukan 10 (sepuluh) jenis kesalahan konsep yang dialami mahasiswa pada topik ikatan kimia. Kesepuluh jenis kesalahan konsep tersebut, dapat dilihat pada Tabel 1.

Kesepuluh jenis kesalahan konsep yang ditemukan melalui tes diagnostik two-tier (Tabel1) juga ditemukan jika menggunakan tes peta konsep dan wawancara, meskipun dengan persentase yang berbeda. Salah satu contoh peta konsep mahasiswa yang mengalami kesalahan konsep pada sub topik unsur-unsur penyusun senyawa kovalen dan ionik dapat dilihat pada Gambar 1.

Kesalahan konsep tersebut juga terkonfirmasi pada hasil wawancara antara peneliti (P) dan mahasiswa M. Cuplikan wawancara terhadap salah satu

Tabel 1. Jenis Kesalahan Konsep yang Dialami Mahasiswa, Berdasarkan Tes Two Tier

\begin{tabular}{|c|c|c|c|}
\hline Subtopik & & Kesalahan Konsep & Jumlah (\%) \\
\hline $\begin{array}{l}\text { Unsur-unsur penyusun } \\
\text { senyawa kovalen dan ionik }\end{array}$ & 1. & Semua senyawa kovalen tersusun dari unsur-unsur non logam. & 25,00 \\
\hline \multirow[b]{2}{*}{ Ikatan rangkap } & 2. & $\begin{array}{l}\text { Pemutusan ikatan rangkap dua dan rangkap tiga, masing-masing membutuhkan } \\
\text { energi dua dan tiga kali lipat energi pemutusan ikatan tunggal. }\end{array}$ & 25,00 \\
\hline & 3. & Ikatan tunggal, ikatan rangkap dua, dan ikatan rangkap tiga adalah sama panjang & 20,83 \\
\hline \multirow[b]{2}{*}{ Ikatan kovalen koordinasi } & & $\begin{array}{l}\text { Ikatan kovalen koordinasi selalu lebih lemah daripada ikatan kovalen biasa se- } \\
\text { hingga panjang ikatan antar atom yang berikatan kovalen koordinasi lebih pan- } \\
\text { jang. }\end{array}$ & \multirow[t]{2}{*}{16,67} \\
\hline & & $\begin{array}{l}\text { Ikatan kovalen koordinasi selalu lebih kuat daripada ikatan kovalen biasa sehing- } \\
\text { ga panjang ikatan antar atom yang berikatan kovalen koordinasi lebih pendek. }\end{array}$ & \\
\hline \multirow[t]{2}{*}{ Ikatan kovalen polar } & & $\begin{array}{l}\text { Pada molekul kovalen polar pasangan elektron ikatan terletak pada jarak yang } \\
\text { selalu sama diantara kedua atom yang berikatan }\end{array}$ & \multirow[b]{2}{*}{70,83} \\
\hline & & $\begin{array}{l}\text { Pasangan elektron ikatan pada ikatan kovalen polar lebih tertarik ke atom yang } \\
\text { memiliki ukuran lebih besar. }\end{array}$ & \\
\hline Kepolaran molekul & & $\begin{array}{l}\text { Molekul polar terbentuk karena adanya ikatan kovalen polar yang terjadi antara } \\
\text { atom logam dan atom non logam }\end{array}$ & 8,33 \\
\hline \multirow{2}{*}{$\begin{array}{l}\text { Aturan oktet, muatan for- } \\
\text { mal, dan, kestabilan senya- } \\
\text { wa kovalen. }\end{array}$} & & Keelektronegatifan suatu unsur menentukan nilai muatan formalnya & \multirow[b]{2}{*}{41,67} \\
\hline & & Ikatan yang terjadi antar atom-atom semuanya untuk memenuhi aturan oktet & \\
\hline
\end{tabular}

Keterangan : Jumlah (\%) adalah persentase mahasiswa yang mengalami miskonsepsi dari keseluruhan 24 mahasiswa

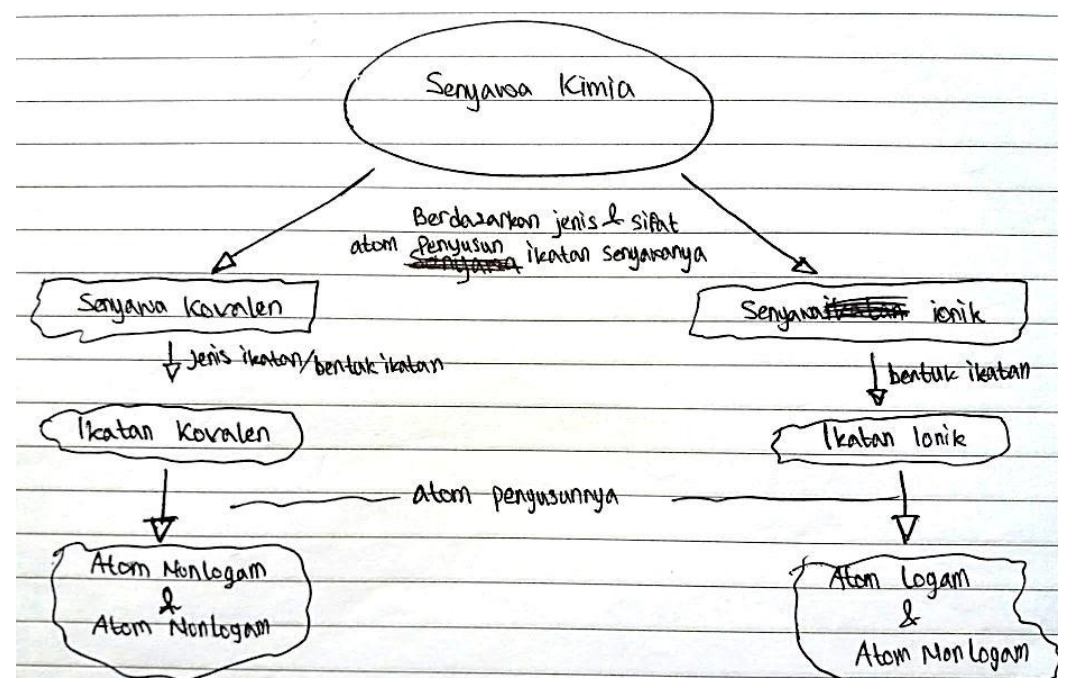

Gambar 1. Peta Konsep Mahasiswa yang Mengalami Kesalahan Konsep Jenis No.1 (Tabel 1) 
mahasiswa yang mengalami kesalahan konsep pada sub topik no. 1 unsur-unsur penyusun senyawa kovalen dan ionik adalah sebagai berikut.

P : "Apa yang dimaksud dengan senyawa ionik dan senyawa kovalen?"

$M$ : "Senyawa ionik adalah senyawa yang terbentuk akibat adanya ikatan ionik sedangkan senyawa kovalen adalah senyawa yang terbentuk akibat adanya ikatan kovalen".

$P$ : "Kalau pengertian ikatan ionik dan ikatan kovalen?"

M : "Ikatan ionik adalah ikatan yang terbentuk dari atom logam dan atom non logam sedangkan ikatan kovalen terbentuk dari atom-atom non logam".

$P$ : Baik, kalau begitu coba sebutkan contoh senyawa ionik dan senyawa kovalen!"

$\mathrm{M}$ : "Ee contohnyaa $\mathrm{NaCl}, \mathrm{CaCl}$, dan $\mathrm{MgCl}_{2}$ itu contoh senyawa ionik trus kalau contohnya senyawa kovalen $\mathrm{H}_{2} \mathrm{O}$ dan $\mathrm{CO}_{2}$ "

$P$ : "Kalau $\mathrm{BeCl}_{2}$ termasuk senyawa ionik atau senyawa kovalen?"

$M$ : (berpikir sejenak) "Senyawa ionik, eh bentarbentar pak, oh iya senyawa ionik pak kan Be atom logam dan Cl atom non logam”.

$P$ : "Jadi kalau begitu ikatan kovalen itu terjadi antar atom non logam dan ikatan ionik terjadi antara atom logam dengan atom non logam?"

$M$ : "Iya pak sepemahaman saya seperti itu"

Mahasiswa tersebut mengalami kesalahan konsep jenis no. 1 (Tabel1), karena pengaruh dari pembelajaran dan buku teks kimia SMA, yang sering mengaitkan dikotomi pada unsur-usur kimia yaitu logam dan non logam dengan jenis ikatan pada suatu senyawa kimia (Nahum, dkk., 2007). Hal ini dikarenakan tidak semua senyawa kimia yang tersusun atas atom logam dan atom non logam merupakan senyawa ionik, misalnya $\mathrm{BeCl}_{2}$ yang merupakan senyawa kovalen. Penentuan jenis ikatan kimia dapat dilihat secara berkelanjutan mulai dari ikatan ionik, ikatan kovalen polar, dan ikatan kovalen non polar berdasarkan penurunan beda keelektronegatifan antar atom-atom penyusun senyawa kimia (Taber, 2011). Ikatan ionik terjadi jika beda keelektronegatifan antar atom lebih dari 1,7 berdasarkan skala Pauling dan jika beda keelektronegatifan antar atom kurang dari 1,7, maka ikatan yang terbentuk merupakan ikatan kovalen (Effendy, 2012). Berdasarkan konsep tersebut, senyawa ionik maupun senyawa kovalen dapat tersusun dari atom logam dengan atom non logam maupun antar atomatom non logam.

\section{Struktur Pengetahuan Mahasiswa}

Struktur pengetahuan mahasiswa dianalisis dengan cara memberikan skor pada peta konsep yang dibuat oleh mahasiswa. Penilaian didasarkan atas kebenaran dan kelengkapan petakonsep yang dibuat serta, kualitas setiap frasa penghubung antar konsep. Skor yang diperoleh oleh masing-masing maasiswa kemudian direkap dan direrata, untuk selanjutnya diinterpretasikan dan digolongan menjadi beberapa kategori. Hasil analisis terhadap tingkat struktur pengetahuan awal mahasiswa berdasarkan tes peta konsep tersebut dapat dilihat pada Tabel 2 .

Tabel 2. Tingkat Struktur Pengetahuan Awal Mahasiswa pada Topik Ikatan Kimia

\begin{tabular}{lc}
\hline $\begin{array}{c}\text { Tingkat Struktur Pengetahuan } \\
\text { Mahasiswa }\end{array}$ & Jumlah (\%) \\
\hline Sangat tinggi & - \\
Tinggi & - \\
Sedang & 12,50 \\
Rendah & 66,67 \\
Sangat rendah & 20,83 \\
\hline
\end{tabular}

Berdasarkan Tabel 2, diketahui bahwa sebagian besar mahasiswa yaitu sebesar $66,67 \%$ memiliki tingkat struktur pengetahuan awal yang rendah.

\section{Kesesuaian Hasil Identifikasi Kesalahan Konsep Berdasarkan Hasil Tes Peta Konsep dengan Tes Diagnostik Two-Tier.}

Tujuan dari pengukuran ini adalah untuk mengetahui kemampuan tes peta konsep dalam menjaring kesalahan konsep mahasiswa relativ terhadap tes diagnostik two tier sebagai suatu tes standar. Persentase kesesuaian antara hasil identifikasi kesalahan konsep menggunakan tes peta konsep dan tes diagnostik two-tier dapat dilihat pada Tabel 3.

Tabel 3. Persentase Kesesuaian Hasil Identifikasi Kesalahan Konsep antara Tes Peta Konsep dengan Tes Two-tier

\begin{tabular}{cccc}
\hline $\begin{array}{c}\text { Jenis Kesa- } \\
\text { lahan Konsep }\end{array}$ & $\begin{array}{c}\text { Jumlah mahasiswa yang } \\
\text { Nongalami kesalahan } \\
\text { konsep berdasarkan tes }\end{array}$ & $\begin{array}{c}\% \\
\text { Kesesuaian }\end{array}$ \\
\cline { 2 - 3 } & Peta konsep & Two-tier & \\
\hline 1 & 6 & 6 & 100,00 \\
2 & 2 & 9 & 22,22 \\
3 & 0 & 5 & 0,00 \\
4 & 2 & 3 & 66,67 \\
5 & 2 & 1 & 50,00 \\
6 & 0 & 15 & 0,00 \\
7 & 1 & 2 & 50,00
\end{tabular}




\begin{tabular}{cccc}
\hline $\begin{array}{c}\text { Jenis Kesa- } \\
\text { lahan Konsep } \\
\text { No. }\end{array}$ & $\begin{array}{c}\text { Jumlah mahasiswa yang } \\
\text { mengalami kesalahan } \\
\text { konsep berdasarkan tes }\end{array}$ & $\begin{array}{c}\text { \% } \\
\text { Kesesuaian }\end{array}$ \\
\cline { 2 - 3 } & $\begin{array}{ccc}\text { Peta konsep } \\
\text { Two-tier }\end{array}$ & \\
\hline 8 & 2 & 2 & 100,00 \\
9 & 2 & 2 & 100,00 \\
10 & 8 & 8 & 100,00 \\
\hline Jumlah & $\mathbf{2 7}$ & $\mathbf{5 3}$ & \\
\hline \% & & & $\mathbf{5 0 , 9 4}$ \\
Kesesuaian & & & \\
\hline
\end{tabular}

Berdasarkan Tabel 3, dapat diketahui bahwa hasil identifikasi kesalahan konsep menggunakan tes peta konsep tidak begitu akurat, karena hanya ditemukan 27 mahasiswa yang mengalami kesalahan konsep, sementara jika menggunakan dengan hasil identifikasi kesalahan konsep menggunakan tes diagnostik two-tier ditemukan 53 mahasiswa. Oleh karenanya rerata kesesuaian hasilnya dengan tes two tier tergolong sedang saja, yaitu rata-rata sebesar 50,94\%. Hal ini menunjukkan bahwa teknik tes peta konsep memiliki keterbatasan dalam mengungkap kesalahan konsep yang terjadi. Peta konsep memiliki keterbatasan dalam menggambarkan hubungan antar konsep yang bersifat khusus dan detail, karena peta konsep cenderung hanya melihat hubungan antar konsep secara umum (Watskins, R., dkk, 2011). Selain itu, peta konsep mahasiswa yang sangat sederhana juga menghambat pengungkapan kesalahan konsep yang terjadi berdasarkan interpretasi peta konsep, karena gambaran pemahaman konsepnya tidak maksimal (Borda, dkk., 2009). Untuk itu masih diperlukan teknik lain misalnya teknik wawancara untuk dapat mengkonfirmasi kesalahan konsep melalui tes tersebut.

\section{Keefektifan Wawancara Berbasis Konflik Kog- nitif dalam Memperbaiki Struktur Pengetahuan dan Kesalahan Konsep Mahasiswa.}

Keefektifan wawancara berbasis konflik kognitif dalam memperbaiki kesalahan konsep dapat dilihat dari pengurangan kesalahan konsep setelah dilakukan perbaikan menggunakan teknik wawancara berbasis konflik kognitif. Rekapitulasi pengurangan kesalahan konsep mahasiswa sesudah dilakukan wawancara berbasis konflik kognitif pada topik ikatan kimia dapat dilihat pada Tabel 4.

Berdasarkan Tabel 4 diketahui bahwa wawancara berbasis konflik kognitif mampu memperbaiki kesalahan konsep dengan nilai rata-rata sebesar $75,47 \%$ yang tergolong tinggi. Perbedaan \% kesalahan konsep sebelum dan sesudah wawancara telah dikonfirmasi menggunakan uji-t berpasangan yang hasilnya menunjukkan perbedaan yang signifikan (Tabel 4).

Tabel 4. Rekapitulasi Pengurangan Kesalahan Konsep Mahasiswa Sesudah Wawancara Berbasis Konflik Kognitif pada Topik Ikatan Kimia

\begin{tabular}{cccc}
\hline \multirow{4}{*}{$\begin{array}{c}\text { No. Kesalahan } \\
\text { Konsep }\end{array}$} & $\begin{array}{c}\text { Jumlah Mahasiswa } \\
\text { yang mengalami } \\
\text { Kesalahan Konsep }\end{array}$ & $\begin{array}{c}\text { Pengurangan } \\
\text { Kesalahan }\end{array}$ \\
\cline { 2 - 3 } & $\begin{array}{c}\text { Sebelum } \\
\text { wawan- } \\
\text { cara }\end{array}$ & $\begin{array}{c}\text { Sesudah } \\
\text { Wawan- } \\
\text { cara }\end{array}$ \\
\hline 1 & 6 & 2 & 66,67 \\
2 & 9 & 2 & 77,78 \\
3 & 5 & 1 & 80,00 \\
4 & 3 & 1 & 66,67 \\
5 & 1 & 0 & 100,00 \\
6 & 15 & 2 & 86,67 \\
7 & 2 & 1 & 50,00 \\
8 & 2 & 0 & 100,00 \\
9 & 2 & 1 & 50,00 \\
10 & 8 & 3 & 62,50 \\
\hline Rata-rata & & & $\mathbf{7 5 , 4 7}$ \\
\hline
\end{tabular}

Tabel 5. Hasil Uji beda antara Rerata Pemahaman Mahasiswa Sebelum dan Sesudah Wawancara, Baik yang Meggunakan Tes Two Tier Maupun yang Menggunakan Tes Peta Konsep

\begin{tabular}{lccc}
\hline \multirow{2}{*}{$\begin{array}{l}\text { Jenis Tes yang } \\
\text { digunakan }\end{array}$} & $\begin{array}{c}c \\
\text { Rata-rata }\end{array}$ & Pemahaman Siswa (\%) & $\begin{array}{c}\text { Signifikansi } \\
\text { (2-tailed) }\end{array}$ \\
\cline { 2 - 3 } & Sebelum & Sesudah & \\
\hline $\begin{array}{l}\text { Diagnostik } t w o- \\
\text { tier (tentang } \\
\text { pemahaman } \\
\text { konsep) }\end{array}$ & 25,23 & 60,42 & 0,000 \\
$\begin{array}{l}\text { Peta konsep } \\
\text { (tentang struktur } \\
\text { pengetahuan) }\end{array}$ & 32,25 & 62,35 & \\
\hline
\end{tabular}

Berdasarkan Tabel 5, diketahui bahwa nilai signifikansi pada uji rerata pemahaman sebelum dan sesudah wawancara masing-masing sebesar 0,000 , jadi $<0,05$. Hal ini berarti bahwa ada perbedaan pemahaman konsep dan struktur pengetahuan mahasiswa sebelum dan sesudah diberikan perlakuan wawancara berbasis konflik koqnitiv. Perbedaan tersebut berupa peningkatan pemahaman konsep mahasiswa dari rata-rata $25,23 \%$ menjadi $60,42 \%$ dan struktur pengetahuan mahasiswa yang meningkat dari rata-rata $32,25 \%$ menjadi $62,35 \%$. Sehingga wawancara berbasis konflik kognitif terbukti efektif dalam memperbaiki kesalahan konsep dan struktur pengetahuan mahasiswa. 


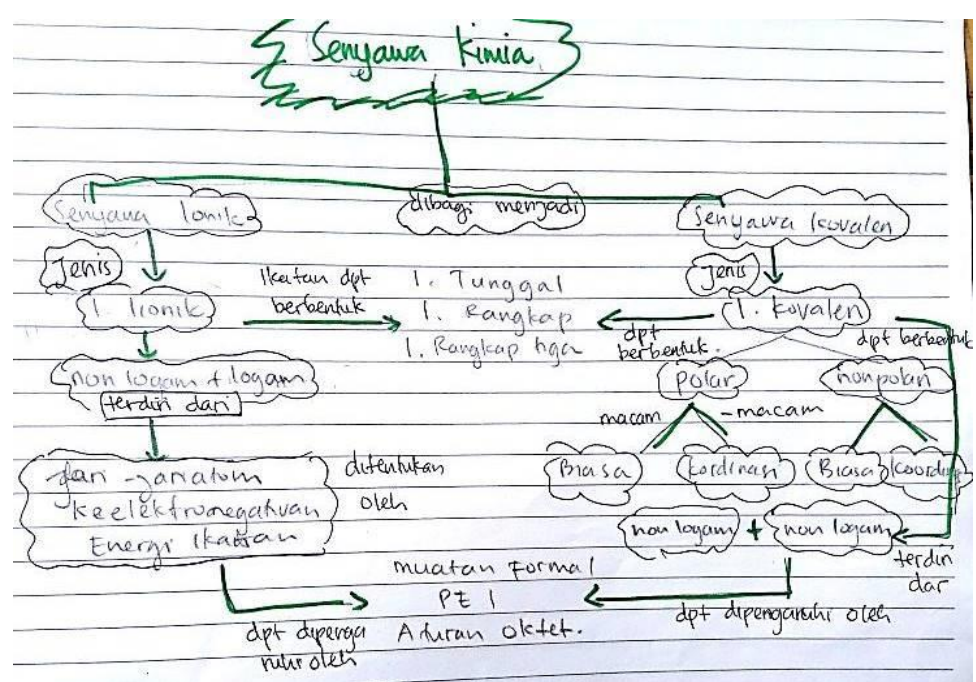

(a)

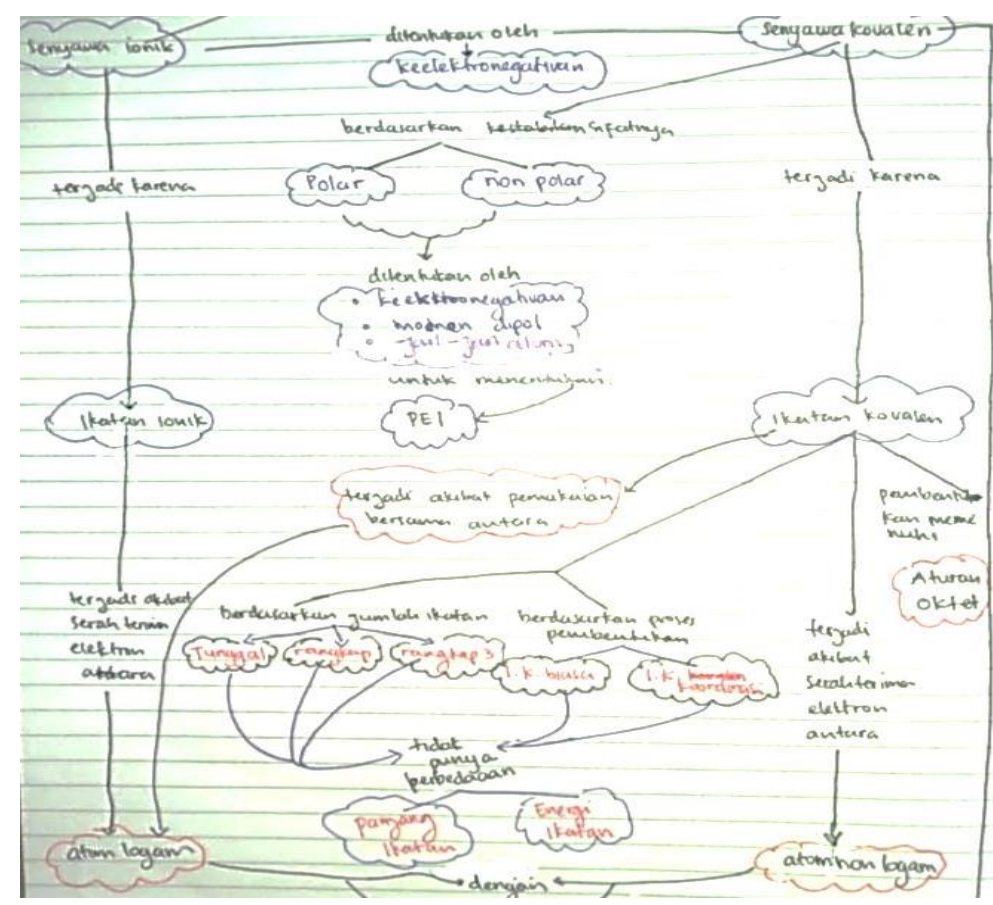

(b)

\section{Gambar 2. Peta Konsep Mahasiswa Sebelum Perlakuan (a) dan Sesudah Perlakuan (b)}

Peningkatan pemahaman konsep dan struktur pengetahuan tersebut menunjukkan bahwa pemahaman konsep memiliki hubungan yang linear dengan struktur pengetahuan. Hal ini sejalan dengan pendapat Novak (2010) bahwa struktur pengetahuan adalah skema yang dibuat oleh pebelajar dalam mengatur dan menghubungkan berbagai konsep untuk memahami topik pembelajaran tertentu. Oleh karena itu, perubahan struktur pengetahuan mahasiswa diduga merupakan faktor utama yang menyebabkan wawancara berbasis konflik kognitif efektif dalam memperbaiki kesalahan konsep yang ada.
Wawancara berbasis konflik kognitif berpotensi memperbaiki struktur pengetahuan mahasiswa melalui proses adaptasi dengan cara memunculkan keadaan disequilibrium pada struktur pengetahuan mahasiswa. Proses adaptasi terdiri atas proses asimilasi dan akomodasi (Hitipheuw, 2009). Proses asimilasi adalah proses dimana mahasiswa menggunakan konsep-konsep yang telah dimiliki pada struktur pengetahuannya untuk berhadapan dengan fenomena baru, sedangkan pada proses akomodasi mahasiswa mengubah struktur pengetahuan awalnya untuk menyesuaikannya agar sesuai dengan fenomena baru yang mereka hadapi. Bukti 
terjadinya proses asimilasi dan akomodasi pada struktur pengetahuan mahasiwa tergambar dari hasil tes peta konsep (Gambar 2). Salah satu peta konsep mahasiswa yang mengalami kesalahan konsep jenis 1 (Tabel1) menghasilkan peta konsep seperti pada Gambar 2a , dan setelah perlakuan wawancara berbasis konfik koqnitiv, menghasilkan peta konsep seperti pada Gambar 2b.

Bukti lain terjadinya proses asimilasi dan akomodasi tercermin pada cuplikan wawancara berbasis konflik kognitif, yaitu pada fase penciptaan kondisi konflik dan fase pemberian bantuan. Cuplikan wawancara terhadap salah satu mahasiswa yang mengalami kesalahan konsep jenis No.1 (Tabel1) adalah sebagai berikut.

$P$ : "Coba perhatikan data titik lebur dan data titik didih senyawa-senyawa berikut ini! (diberikan data titik lebur dan titik didih senyawa-senyawa yang terdiri atas atom-atom golongan 2 yang berikatan dengan atom $\mathrm{Cl}$ ). Menurutmu fenomena apa yang menarik dari data tersebut.

$M$ : "BeCl $\mathrm{B}_{2}$ memiliki titik lebur dan titik didih yang jauh lebih rendah dibandingkan dengan $\mathrm{MgCl}_{2}$, $\mathrm{CaCl}_{2}, \mathrm{SrCl}_{2}$, dan $\mathrm{BaCl}_{2}$ ".

$P$ : "Menurutmu apa penyebab tinggi atau rendahnya titik didih dan titik lebur suatu senyawa?"

M :"Ikatannya, pak. Makin kuat ikatannya maka makin susah untuk memutuskannya, sehingga eee.. dibutuhkan energi yang lebih besar untuk memutuskan ikatan tersebut".

$P$ : " Kalau begitu jenis ikatan pada pada $\mathrm{MgCl}_{2}$, $\mathrm{CaCl}_{2}, \mathrm{SrCl}_{2}$, dan $\mathrm{BaCl}_{2}$ itu sama atau kah berbeda dan tentukan jenis ikatan dan senyawanya.

M : "Eee ...(berpikir) Sama kan titik didih dan titik lebur hampir sama. Jenis ikatannya, ikatan ionik maka jenis senyawanya adalah senyawa ionik.

$P$ : "Kalau jenis ikatan pada $\mathrm{BeCl}_{2}$ ?(perhatikan data titik didih dan titik lebur)"

M : "Karena titik didih dan titik leburnya jauh berbeda dengan $\mathrm{MgCl}_{2}, \mathrm{CaCl}_{2}, \mathrm{SrCl}_{2}$, dan $\mathrm{BaCl}_{2}$ maka jenis ikatannya juga berbeda, sehingga saya menduga ikatannya BeCl2 ikatan kovalen bukan ionik, sehingga $\mathrm{BeCl}_{2}$ bukan senyawa ionik melainkan senyawa kovalen".

$P$ : "Kalau begitu apakah ikatan kovalen itu harus terjadi hanya antar atom-atom non logam saja?"

M : "Tidak, ikatan kovalen juga dapat terjadi antara atom logam dengan atom non logam".
Berdasarkan cuplikan wawancara tersebut, proses asimilasi terlihat pada kemampuan mahasiswa dalam memberikan penjelasan tentang pengaruh kekuatan ikatan antar molekul terhadap titik didih dan titik lebur suatu senyawa. Kemampuan mahasiswa dalam memberikan penjelasan pengaruh kekuatan ikatan terhadap titik didih dan titik lebur suatu senyawa, menandakan adanya struktur pengetahuan mahasiswa tentang konsep-konsep, titik didih, titik lebur, dan ikatan kimia. Selanjutnya mahasiswa menghubungkan konsep-konsep tersebut untuk menyesuaikan struktur pengetahuannya dengan fenomena baru (anomali) yang diberikan, yaitu bahwa titik lebur dan titik didih yang jauh berbeda dari Be khlorida dibanding khlorida unsur segolongannya. Proses asimilasi tersebut mengakibatkan mahasiswa mendapatkan pengetahuan baru yang akan memperkaya struktur pengetahuannya.

Proses akomodasi juga terlihat saat mahasiswa mengubah struktur pengetahuan awalnya menyesuaikan dengan fenomena baru yang mereka hadapi. Fenomena baru tersebut adalah bahwa $\mathrm{BeCl}_{2}$ bukan merupakan senyawa ionik, tetapi ikatan kovalen meskipun terbentuk atas atom logam dan atom non logam, hal ini dikarenakan perbedaan titik didih dan titik lebur $\mathrm{BeCl}_{2}$ yang sangat jauh berbeda berbeda dengan $\mathrm{MgCl}_{2}, \mathrm{CaCl}_{2}, \mathrm{SrCl}_{2}$, dan $\mathrm{BaCl}_{2}$ yang merupakan senyawa ionik. Fenomena ini menimbulkan disequilibrium karena fenomena ini bertentangan dengan pemahaman yang selama ini diyakini mahasiswa yaitu bahwa suatu ikatan ionik hanya terjadi antara atom logam dengan atom non logam dan ikatan kovalen hanya terjadi antar atomatom non logam. Untuk mencapai kondisi equilibrium yang baru maka mahasiswa harus mengubah struktur pengetahuannya menuju konsep yang benar, yaitu bahwa ikatan kovalen dapat terjadi baik antara atom logam dengan atom non logam, maupun antar atom-atom non logam. Hal ini menunjukkan bahwa wawancara berbasis konflik kognitif mampu memperbaiki kesalahan konsep mahasiswa.

Hasil penelitian ini sejalan dengan temuantemuan terdahulu bahwa peta konsep dapat memvisualisasikan struktur pengethuan mahasiswa dan mengenali kesulitan mahasiswa pada mata kuliah kimia dasar (Farncisco, dkk, 2006); peta konsep mampu mengungkap perbedaan struktur pengetahuan mahasiswa dengan struktur pengetahuan para ahli tentang konsep elektrofil dan nukleofil, di mana umunya mahasiswa tidak mampu membuat hubungan yang koheren antar konsep (Anzovino \& Bretz , 2016). Penggunaan peta konsep untuk mengungkap struktur pengetahuan mahasiswa pada topik ikatan kimia juga pernah dilakukan oleh Burrows \& 
Mooring (2014), tetapi di samping subjek penelitian yang berbeda, penelitian itu belum juga belum mengungkap seberapa jauh tingkat kesesuaian antara kesalahan konsep yang ditemukan dengan tes peta konsep dibanding dengan yang ditemukan kalau menggunakan tes two tier.

\section{SIMPULAN}

Berdasarkan hasil penelitian dan pembahasan yang telah dipaparkan, maka dapat disimpulkan bah-

\section{DAFTAR RUJUKAN}

Anzovino, M. E. \& Bretz, S. L. 2016 . Organic Chemistry Students' Fragmented Ideas about the Structure and Function of Nucleophiles and Electrophiles: A Concept Map Analysis. Chemical Education Research And Practice, 17, 1019-1029.

Burrows \& Mooring, N. L. \& Mooring, S. R. 2014. Using Concept Mapping to Uncover Students' Knowledge Structures of Chemical Bonding Concepts. Chemical Education Research And Practice, 16(1), 1-14.

Borda, J.E., Burgess, D. J.,Plog, C. J., Dekalb, N. C. \& Luce, M. M. 2009. Concept Maps as Tools For Assesing Students Epistemologies of Science. Electronic Journal of Science Education, 13(2), $160-185$

Bretz, S. L. 2007. Qualitative Research Designs in Chemistry Education Research. In D. M. Bunce and R. S. Cole (Ed.), Nuts and Bolts of Chemical Education Research (pp. 79-99). Washington, D.C.: American Chemical Society.

Creswell, J.W. 2016. Research Design Pendekatan Metode Kualitatif, Kuantitatif, dan Campuran, Edisi Keempat. Terjemahan Achmad Fawaid dan Rianayanti Kusmini Pancasari. Yogyakarta: Pustaka Pelajar. 2014.

Effendy. 2012. A-Level Chemistry for Senior High School Students Vol 1B. Malang : Bayu Media.

Fajar, A. 2014. Menggali Pemahaman Konsep siswa SMA pada Topik Ikatan Kimia menggunakan Instrumen Diagnostik Two-Tier. Skripsi tidak dipublikasikan. Malang: Universitas Negeri Malang.

Francisco, J. S., Nakleh, M. B., Nurrenbern, S. C., \& Miller, M. L. 2006. Assessing Student Understanding of General Chemistry with Concept Mapping. Journal of Chemical Education, 79(2), 248-257.

Hitipeuw, I. 2009. Belajar dan Pembelajaran. Malang: Fakultas Ilmu Pendidikan Universitas Negeri Malang.

Khodaryah, N. 2010. Analisis Kesalahan Konsep tentang Larutan Buffer pada Siswa Kelas XI SMAN 2 dan SMA YPK Bontang serta Upaya untuk Memperbaiki dengan Menggunakan Strategi Konflik wa pada mahasiswa yang menjadi subjek penelitian ini (1) terdapat 10 jenis kesalahan konsep pada topik ikatan kimia, dan tingkat kesesuaian identifikasi kesalahan konsep menggunakan tes peta konsep dan tes diagnostik two-tier rata-rata sebesar 50,94\% (sedang), (2) sebagian besar mahasiswa $(66,67 \%)$ memiliki struktur pengetahuan yang rendah dan dan (3) wawancara berbasis konflik kognitif efektif dalam memperbaiki kesalahan konsep dan struktur pengetahuan mahasiswa.

Kognitif. Tesis tidak dipublikasikan. Malang: Jurusan Pendidikan Kimia, PPS UM.

Linenberger K. J. \& Bretz, S. L. 2012. Generating Cognitive Dissonance in Student Interviews through Multiple Representations. Chemical. Education Research and Practice., 13, 172-178.

Lopez E. J., Shavelson R. J., Nandagopal K., Szu E. \& Penn J. 2014. Factors Contributing to ProblemSolving Performance in First-Semester Organic Chemistry. J. Chem. Educ, 91(7), 976-981.

Luxford C. J. \& Bretz S. L. 2013. Moving Beyond Definitions: What Student-Generated Models Reveal about Their Understanding of Covalent Bonding and Ionic Bonding, Chemical Education Research And Practice, 14, 214 -222.

Luxford C. J. \& Bretz S. L. 2014. Development of the Bonding Representations Inventory to Identify Student Misconceptionsabout Covalent and Ionic Bonding Representations, J. Chem. Educ., 91(3), $312-320$.

Nahum, L. T., Naman, R. M., \& Hofstein, A. 2007. Developing a New TeachingApproach for the Chemical Bonding Concept Aligned with Current Scientific and Pedagogical Knowledge, Science Education, 91(4), 579-603.

Novak, J.D, 2010, Learning, Creating, and Using Knowledge: Concept Maps as Facilitative Tools in Schools and Corporations. Journal of E-Learning and Knowledge Society. 6(3), 21 - 30.

Schönborn K. J., Anderson T. R. \& Mnguni L. E., . 2007. Methodsto determine the Role of External Representations in Developing Understanding in Biochemistry. In D. e. a. Lemmermohle (Ed.), Professionell lehren - erfolgreich lernen (pp. 291-301). Munster, Germany: Waxmann.

Taber, K. S. \& Coll R. K.. 2003. Bonding, Chemical Education:Towards Research-based Practice. Springer. 213-234.

Vrabec, M. \& Proksa, M. 2016. Identifying Misconceptions Related to Chemical Bonding Concepts in the Slovak School System Using the Bonding Representations Inventory as a Diagnostic Tool. Journal of Chemical Education, 93(8) : 1364-1370. 
Watkins, R., Meiers, M. W., \& Visser, Y. L. 2011. A Guide to Assesing Needs: Essential Tools for Collecting Information, Making Decisions, and Achieving Development Results. Washington DC: The World Bank
Wheeldon J. P. \& Faubert J. 2009. Framing Experience: Concept Maps, Mind maps, and Data Collection in Qualitative Research. Int. J. Qual. Meth, 8(3), 52-67. 